\title{
Experimental testing for Zarzis port sediments (Tunisia) in road materials
}

\section{Marwa Zelleg}

PhD student, LR 14 ES 03 Laboratoire de Recherche d'Ingénierie

Géotechnique, Ecole Nationale d'Ingénieurs de Tunis, Université de Tunis El

Manar, Tunis, Tunisia

Imen Said

Assistant Professor in Civil Engineering, LR 14 ES 03 Laboratoire de

Recherche d'Ingénierie Géotechnique, Ecole Nationale d'Ingénieurs de

Tunis, Université de Tunis El Manar, Tunis, Tunisia

\author{
Essaieb Hamdi \\ Professor in Civil Engineering, LR 14 ES 03 Laboratoire de Recherche \\ d'Ingénierie Géotechnique, Ecole Nationale d'Ingénieurs de Tunis, Université de \\ Tunis El Manar, Tunis, Tunisia \\ Zoubeir Lafhaj \\ Professor in Civil Engineering, Ecole Centrale de Lille, Villeneuve-d'Ascq, France \\ (corresponding author: zoubeir.lafhaj@ec-lille.fr) (Orcid:0000-0003-1985-9176)
}

This study focused on the feasibility of Tunisian sediment reuse as new road material. Experiments were conducted to investigate sediment reuse as road material. Three mixtures (raw sediments, stabilised sediments with $3 \%$ lime and stabilised sediments with $3 \%$ cement) were studied with regard to their mechanical performances. The first part of this paper introduces the characterisation of Zarzis sediments. The second part describes the laboratory experiments and the followed methods. The third part is dedicated to the analysis of results. The originality of this work is the use of a minimum percentage of lime, which was determined experimentally. Based on environmental tests, Zarzis sediments were uncontaminated. Thus, they can be reused directly without a decontamination treatment process. Results show that humic compounds complicated sediment treatment with cement. Therefore, cement did not present an appropriate binder for stabilising and solidifying the investigated sediments. Based on mechanical results, a mixture with $3 \%$ lime can be used as new road material.

\section{Notation}

E elastic modulus

$F_{\mathrm{r}} \quad$ failure strength

h sample height

$I_{\mathrm{CBR}} \quad$ immediate California bearing ratio

$L_{\mathrm{L}} \quad$ liquid limit

$P_{\mathrm{L}} \quad$ plastic limit

$R_{\mathrm{t}} \quad$ tensile strength

$R_{\mathrm{tb}} \quad$ compressive resistance along the sample length

$U_{\mathrm{CS}} \quad$ unconfined compressive strength

$\gamma_{\mathrm{s}} \quad$ specific unit weight

$\phi \quad$ sample diameter

\section{Introduction}

Sediments are defined as the union of organic or mineral particles transported, precipitated and accumulated at the bottom of lakes, rivers (river sediments) or harbours (marine sediments) (Adams et al., 1992). Sediments in estuaries and harbour areas are essential components of the marine ecosystem that ensure the development of various aquatic organisms. These sediments are in constant contact with pollutants coming primarily from industrial waste and maritime traffic. The pollutants trapped in sediments can migrate to the fauna, flora and individuals and damage their health. These can pose a major ecological and environmental hazard (Adams et al., 1992; Hu et al., 2006; Rosenberg, 1977).

Marine sediments must be periodically dredged in harbours all over the world to ensure sufficient depth of water, to maintain harbour waterways and to reduce the risk of pollution of the marine ecosystem. According to statistics (Ices, 2011; Le Guyader and Colin, 2012), the Netherlands presents the greatest quantity of dredged sediments with a volume of 122 million $\mathrm{m}^{3}$ over the next 10 years.
Dredging is the first step in harbour management. Before dredging, an environmental analysis is made. The results are used to decide on the management method: dumping at sea or depositing on land. Land management poses problems because of the large volume and level of contamination. Dredging operation managers are required to adopt the least damaging solution for the environment. Thus, the usual solutions are used - namely, dumping at sea, land disposal with or without confinement, hopper overflow dredging, dredging by resuspension of sediments and formation of artificial islands from dredged sediments. Dumping at sea is permitted only when the concentrations of heavy metals and organic pollutants in sediments are below acceptability thresholds fixed by regulations. However, hydrodynamic agents in the discharge site may contribute to sediment remobilisation towards the harbour. Therefore, hydrodynamic effects are considered in the choice of disposal sites at sea to avoid sediment remobilisation. Land disposal requires monitoring and permanent maintenance. Dumping at sea and land disposal are constrained by national and international regulations and conventions such as Directive 2008/56/EC of the European Commission (EC, 2008), the Oslo/Paris Convention (Ospar Convention, 1992), the London Convention (IMO, 1972, 2013) and the Barcelona Convention (2011). Hence, sediment reuse becomes a key step in the methodology of harbour management in order to balance the costs of dredging and eliminate the migration risk of contamination to the environment. To achieve this goal, the economical point of view must be considered in the recycling of sediments, but this is not considered in this paper.

Researchers have started to study ways to reuse marine sediments in various building construction materials such as clay bricks (Hamer and Karius, 2002; Lafhaj et al., 2008; Weng et al., 2003), cementitious materials (Agostini et al., 2007; Limeira et al., 2011; Wang, 2009) and paving blocks (Said et al., 2015). 
In civil engineering, road engineering consumes a significant amount of aggregates with different mechanical properties. Indeed, the recommended minimum values of the immediate California bearing ratio $(\mathrm{CBR})\left(I_{\mathrm{CBR}}\right)$ change from one layer to another. Mechanical properties, such as unconfined compressive strength $\left(U_{\mathrm{CS}}\right), \mathrm{CBR}$ values and indirect tensile strength (ITS), depend on the class of the road and the position of the material in the pavement structure (Scordia et al., 2008). Thus, a wide range of materials is used in road engineering. Road engineering is a solution for dredged sediment reuse not only for its cost-effectiveness but also for the large volume of sediments needed. The sources of aggregates are theoretically almost limited, and many of them remain unusable for various reasons such as inaccessibility, integration of deposits in urban areas or in classified sites, excessive operating costs or environmental sensitivity problems (Michel, 2006). However, the use of recycled materials, whenever possible, can be an advantageous alternative. Through the literature, many researchers (Boutouil, 1998; Boutouil and Saussaye, 2011; Colin, 2003; Duan, 2008; Kamali et al., 2008; Liang, 2012; Maher et al., 2006; Saussaye, 2013; Scordia et al., 2008; Silitonga, 2010; Zentar et al., 2008) studied the possibility of sediment reuse in road construction. Based on the mineralogical composition and physical characteristics of Dunkirk sediments, Wang et al. (2012) assessed the effects of cement and lime through modified Proctor compaction and $U_{\mathrm{CS}}$ tests. The potential of sediments solidified with cement or lime for road construction is evaluated through a proposed methodology from the $I_{\mathrm{CBR}}$ value. In their reported research work, Wang et al. (2012) characterised Dunkirk sediment as sandy soil. They affirmed that from the point of view of mechanics and applicability in road construction, $6 \%$ cement is an economic and reasonable amount to improve the mechanical performance of sediments. This statement had been justified before by
Colin (2003). Another type of research work was conducted by Tran (2009) on the reuse of sediments on road construction that concerns silty clay materials. The study required the use of corrective sands in formulations in order to obtain better results in terms of compaction and compression.

In the present study, the research work aims to evaluate the feasibility of the reuse of raw dredged sediments as an alternative material for road construction. To achieve this goal, sediments were extracted from the Zarzis harbour in Tunisia. Then, an accurate characterisation of dredged sediments was carried out in order to assess and classify the investigated sediments. The mechanical behaviours of the three mixtures were evaluated and compared to French thresholds recommended in Treatment of Soils with Lime and/or Hydraulic Binders: Application to the Construction of Pavement Base Layers (GTS) (Sétra, 2000). The experimental results on tested formulations demonstrated the feasibility of the beneficial reuse of investigated sediments in road applications. For this reason, modified Proctor, $I_{\mathrm{CBR}}, U_{\mathrm{CS}}$ and ITS tests were carried out. The originality of this work is the use of a minimum percentage of lime, which was determined experimentally, and the application to Tunisian harbour sediments. Zarzis sediments were uncontaminated, which presents an advantage for sediment recycling. Thus, the investigated sediments can be reused directly without performing a pretreatment process.

\section{Materials and methods}

\section{Sampling site}

The Zarzis harbour is located in the south-east of Tunisia as shown in Figure 1. It is approximately $30 \mathrm{~km}$ south of Djerba Island,

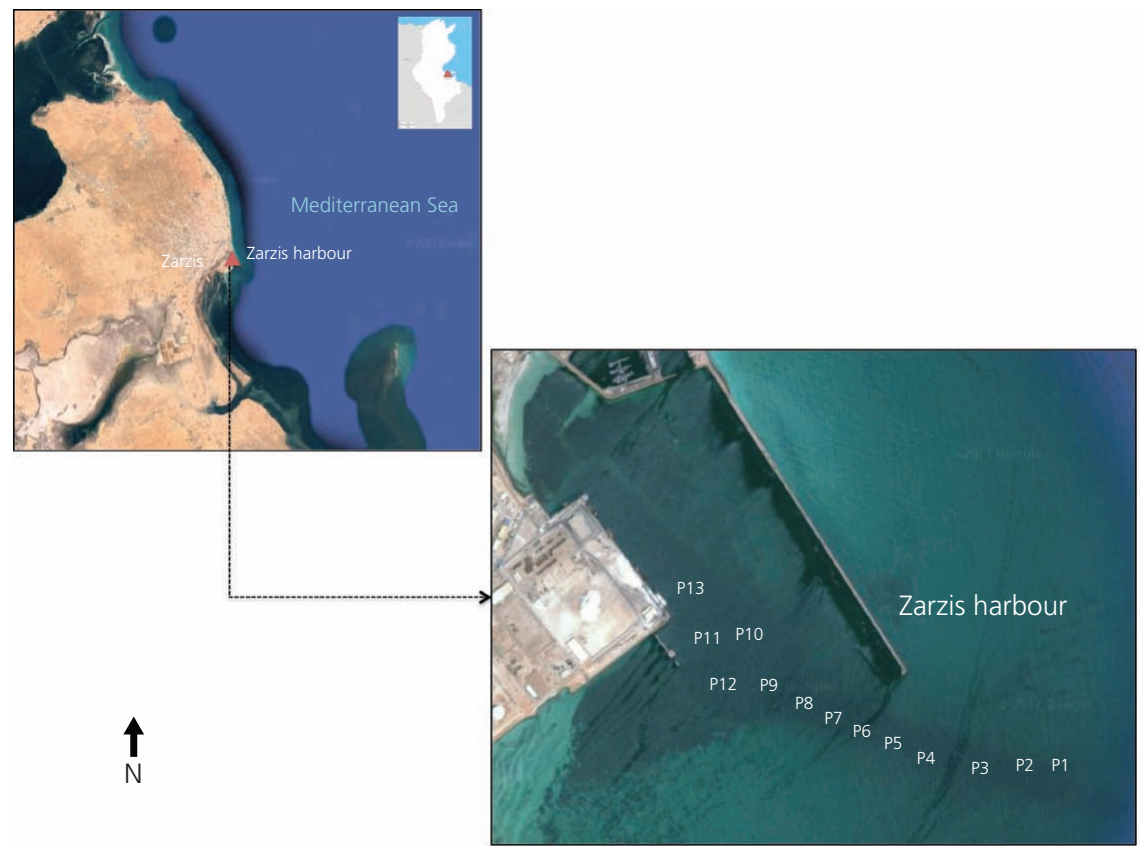

Figure 1. Zarzis harbour corresponding to the studied site emplacement (@) Google Earth, 2017) 
$50 \mathrm{~km}$ from the Gulf of Gabes and $80 \mathrm{~km}$ from the border with Libya. The harbour provides commercial exchanges for the region dealing mainly in the export of marine salt and crude petroleum and import of white oil products (CJB Environnement Inc and EAM, 2006). The Zarzis harbour has an oil wharf located in the extension of the commercial quay on the west side. The harbour has been declared, since 1996, as one of the two free zones in Tunisia. This nomination was intended for enhancing the economic development of the region. However, silting is a major problem in the Zarzis harbour that limits ships from accessing the port. The harbour is composed of three sections. The navigation channel, the turning circle and the commercial basin were initially designed with 13,12 and $12 \mathrm{~m}$ water depths, respectively.

The marine sediments tested in present study were sampled from the Zarzis harbour in Tunisia (Figure 1). Samples are designated, as shown in Figure 1, from P1 to P13. The sediments were taken by a diver by using manual sampling. After dredging, all sampled sediments were transported to the laboratory and homogenised to obtain a raw sediment. Raw sediment was stored in hermetic containers.

\section{Materials}

\section{Cement and lime}

Cement treatments are very usual. Since the mechanical requirements for road materials are relatively low (Czerewko and Cross, 2015; Scordia et al., 2008) and based on what is usually used for road construction in Tunisia, ordinary Portland cement CEM I 42.5R was chosen in present study. The lime used in this work was a quicklime because it is the most widely used form on road construction sites. Lime changes the physical and hydric characteristics (Leroueil and Le Bihan, 1996), structure and properties of a fine soil (Cai et al., 2006). It also acts on the organic matter (OM), which inhibits the hydration reaction of cement (Dubois et al., 2009, Mohd Yunus et al., 2017; Tremblay et al., 2002).

\section{Raw sediments}

Characterisation of the physical properties of raw sediments such as particle size distribution, water content, specific unit weight, methylene blue value and $\mathrm{OM}$ content was performed. The sediments were tested at least in triplicate, and the average values were determined.

Determination of the particle size distribution of Zarzis sediments was done by using wet sieving and hydrometer methods according to French standards NF P94-056 (Afnor, 1996) and NF P94-057 (Afnor 1992a). Then, water content determination was performed by desiccation at $50^{\circ} \mathrm{C}$ for $24-72 \mathrm{~h}$ based on the NF P94-050 standard (Afnor 1995), and the specific unit weight $\left(\gamma_{\mathrm{s}}\right)$ for each tested sample was determined using a helium pycnometer. In order to investigate the clay activity of the studied sediments and their water sensitivity, the methylene blue test was carried out using NF P94-068 (Afnor, 1998a). Afterwards, the $\mathrm{OM}$ content of the sample was evaluated by loss on ignition at $450^{\circ} \mathrm{C}$ referring to the XP P94-047 standard (Afnor, 1998b).
Table 1 gives results of the characterisation of Zarzis sediments. The tested sediments are mainly silty sands with an average of $75 \%$ sand, $18 \%$ silt and $7 \%$ clay fraction. Results show the presence of $12.52 \% \mathrm{OM}$, which indicates that Zarzis sediments are moderately organic. The methylene blue value, representing the adsorption capacity of methylene blue on the particle surfaces, is low and correlated with the grain size distribution. However, the plasticity of studied dredged sediments is high.

X-ray fluorescence (XRF) and X-ray diffraction (XRD) analyses of raw sediments were carried out. They allow quantification (by percentage weight) of the main basic chemical components of the sediments.

$\mathrm{XRF}$ analysis showed that the raw sediments mainly consist of calcium (Ca), carbon (C) and silicon ( $\mathrm{Si}$ ) and smaller percentages of chlorine $(\mathrm{Cl})$, magnesium $(\mathrm{Mg})$ and aluminium (Al). Figure 2 illustrates the XRD data obtained. Raw sediments were mainly composed of quartz $\left(\mathrm{SiO}_{2}\right)$ and calcium carbonate $\left(\mathrm{CaCO}_{3}\right)$.

In order to reuse the sediments as road materials, it is necessary to perform environmental characterisation of the heavy metal concentration in the sediment leachates. Indeed, the solid fraction test assesses the total concentration of various trace elements considered as contaminants. The pollution degree of Zarzis sediments was evaluated using inductively coupled plasma (ICP) optical emission spectroscopy according to the EN 12457-3 standard (Afnor, 2002). Tunisian authorities apply the Netherlands standards to study the possibility of sea dumping of dredged sediment according to the

\section{Table 1. Physical properties of Zarzis raw sediments}

$\begin{array}{lc}\text { Water content: \% } & 210 \\ \text { Sand percentage: \% } & 75 \\ \text { Silt percentage: \% } & 18 \\ \text { Clay percentage: \% } & 7 \\ \text { Methylene blue } & 1.20 \\ \text { Liquid limit } L_{\mathrm{L}}: \% & 83.50 \\ \text { Plastic limit } P_{\mathrm{L}}: \% & 66 \cdot 13 \\ \text { Plasticity index } P_{\mathrm{I}} & 17 \cdot 37 \\ \text { OM: \% } & 12.52 \\ \text { Particle density: } \mathrm{g} / \mathrm{cm}^{3} & 1.70\end{array}$

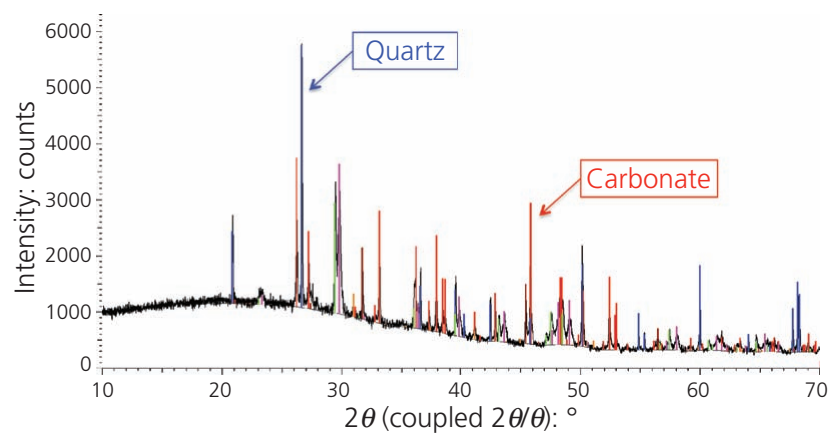

Figure 2. XRD result of raw sediments. Wavelength $=1 \cdot 54060 \AA$ 
results of heavy metal concentrations. Threshold values are respected as strict limit values without exception according to Zoute Bagger Toets (ZBT) values. The latter values were introduced for assessing whether dredged material can be dispersed in the marine environment (DGE, 2007). In the present study, heavy metals in raw sediments are assessed according to the ZBT values.

The concentrations of heavy metals in the leachate of Zarzis sediments (Table 2) were under ICP apparatus detection limit values. Thus, Zarzis sediments may be incorporated into the formulation of an alternative material without any pretreatment process.

\section{Mechanical performance tests}

The minimum recommended tests to determine the feasibility of a specific material to be used in road engineering are the modified Proctor test, $I_{\mathrm{CBR}}$ test, unconfined compression test and indirect tensile test.

The modified Proctor test was performed using the NF P94-093 standard (Afnor, 1993a) in order to know the water content corresponding to the optimal compaction.

The $I_{\mathrm{CBR}}$ index defines the capacity of a material to support vehicle or engine traffic during road construction. It also measures also the ratio of the force required for a circular piston to penetrate into a granular medium in a CBR mould at a speed of $1.27 \pm$ $0 \cdot 1 \mathrm{~mm} / \mathrm{min}$. The prescribed $I_{\mathrm{CBR}}$ values for different road layers are specified in French standard NF P98-115 (Afnor, 1992b). For a subgrade layer, the minimum recommended value of $I_{\mathrm{CBR}}$ is 20 (Sétra, 2000).

The $U_{\mathrm{CS}}$ test was performed according to the NF P98-230-2 standard (Afnor, 1993b). The objective of the $U_{\mathrm{CS}}$ test is the determination of the traffic ability of the subroad layer. According to the NF P98-115 standard, the traffic ability criterion is considered satisfactory since the $U_{\mathrm{CS}}$ is greater than $1 \mathrm{MPa}$. Samples for $U_{\mathrm{CS}}$ test were specifically manufactured using a poly(vinyl chloride) (PVC) sample holder. The specimens were prepared at the optimum water content. The samples were cylindrical with a diameter of $50 \mathrm{~mm}$, a height of $100 \mathrm{~mm}$ and a slenderness equal to 2 .

For the three mixtures, see also the section headed 'Mechanical performance tests' and Table 3; the $U_{\mathrm{CS}}$ values were determined

Table 2. Heavy metal concentrations in raw sediments

\begin{tabular}{lc|} 
Metal & $\begin{array}{c}\text { Heavy metal concentration in raw sediments: } \\
\mathbf{m g} / \mathbf{k g} \text { dry weight }\end{array}$ \\
\hline Cadmium & $<0.001$ \\
Copper & $<0.001$ \\
Nickel & $<0.001$ \\
Zinc & $<0.010$ \\
Chromium & $<0.001$ \\
Lead & $<0.010$
\end{tabular}

Table 3. Designation of mixtures

\begin{tabular}{|lc|}
\hline Mixture & Designation \\
\hline Raw sediments & Raw sediments \\
Sediment stabilised with 3\% lime & SS-3L \\
Sediment stabilised with 3\% cement & SS-3C
\end{tabular}

after 2, 7, 28, 60 and $90 \mathrm{~d}$ of maturation. The samples were stored in normal curing conditions in a room maintained at $20^{\circ} \mathrm{C}$.

In order to study the mechanical tensile performance of the treated layer, ITS $R_{\mathrm{t}}$ values were determined at 28 and $90 \mathrm{~d}$ of maturation. An ITS test was performed on monolithic samples. The specimens were prepared at the optimum water content and using a PVC tube as a mould. The dimensions of the samples for ITS tests are different from those of the $U_{\mathrm{CS}}$ samples. The ITS samples were cylindrical with a diameter of $100 \mathrm{~mm}$, a height of $100 \mathrm{~mm}$ and a slenderness equal to 1 .

The tensile strength, $R_{\mathrm{t}}$, is calculated according to Equations 1 and 2

1. $R_{\mathrm{t}}=0.8 \times R_{\mathrm{tb}}$

2. $R_{\mathrm{tb}}=2 \times 10^{-2} \frac{F_{\mathrm{r}}}{\pi \phi h}$

where $R_{\mathrm{t}}$ is the tensile strength in megapascals; $R_{\mathrm{tb}}$ is the compressive resistance along the sample length - that is, the sample height - in megapascals; $F_{\mathrm{r}}$ is the failure strength in newtons; $\phi$ is the sample diameter in centimetres; and $h$ is the sample height in centimetres.

The elastic modulus, $E$, is deduced from $U_{\mathrm{CS}}$ testing. The mechanical road class is determined with the tensile strength and Young's modulus of a treated material. The mechanical road class corresponds to the zone number, from 1 to 5 , where the material is located in the classification chart defined in GTS (Sétra, 2000). Zone 5 corresponds to the lowest mechanical performance. This classification is important since the cost of layer design depends directly on it. Zone 5 is the minimum required, but contractors usually consider that it is important to be located at least in zone 3 in order to be of technical and economic interest (Scordia et al., 2008).

\section{Mix design}

An experimental study was performed on raw mixed sediments with different percentages of cement or lime to evaluate their reuse potential in road construction. The percentages of lime or cement mixed with fine sediments were fixed to $3 \%$ of the dry mass of raw sediments. The lime content was determined by the limit fixation test. This test consists of measuring the potential of hydrogen $(\mathrm{pH})$ of a demineralised water and sediment solution. A percentage of quicklime was added until the $\mathrm{pH}$ became constant. Figure 3 shows that the $\mathrm{pH}$ stabilised for a lime dosage of $3 \%$. 


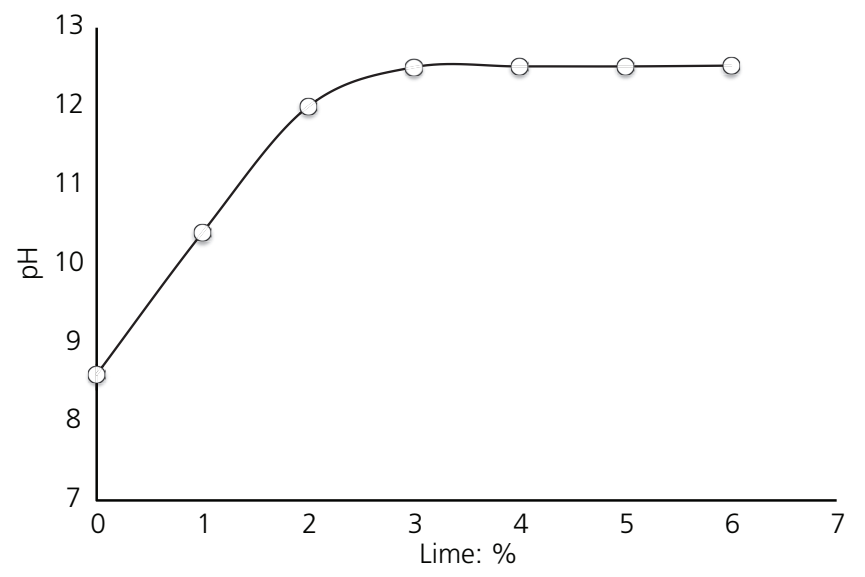

Figure 3. pH plotted against lime percentage

Achour (2013) used the lime saturation curve to determine the minimum percentage of lime. In his study, Achour (2013) investigated the feasibility of reusing sediments in road construction. Marine sediments were dredged from the Grand Port Autonome of Dunkerque and taken from the eastern basin Darse 6. In Achour's (2013) research, the $\mathrm{pH}$ stabilised for a $1 \%$ lime dosage.

Three mixtures were tested in the present study as seen in Table 3. GTS (Sétra, 2000) recommends a maximum of $6 \%$ of cement addition for economic issues. For this reason, 3\% of cement was fixed based on the present study.

The $U_{\mathrm{CS}}$ test, indirect tensile test and elastic modulus determination were performed on each formulation. Raw sediment was mixed with binders (lime or cement) and the optimum water content by using a mixer for $5 \mathrm{~min}$. The samples were cured in a specified room at a constant temperature of $20^{\circ} \mathrm{C}$.

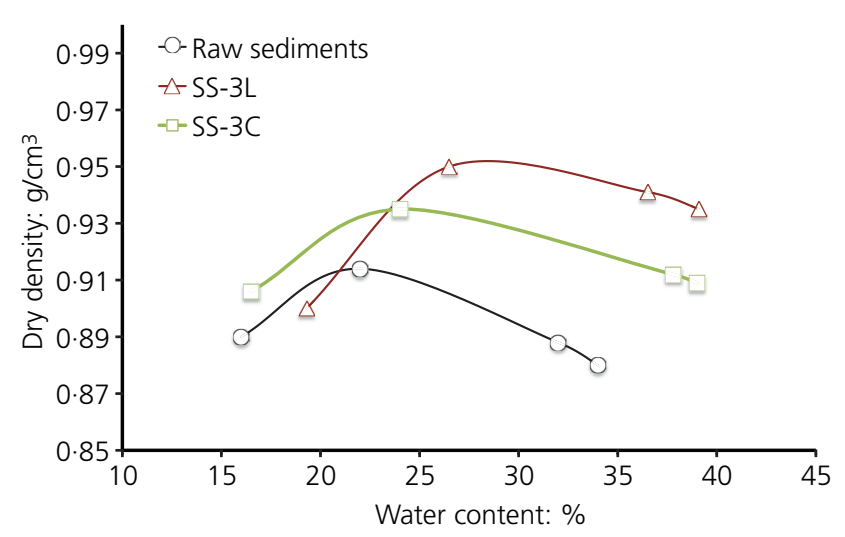

Figure 4. Dry density plotted against water content for raw sediments (black), SS-3L (red) and SS-3C (green)

\section{Results and discussion}

The modified Proctor, $I_{\mathrm{CBR}}, U_{\mathrm{CS}}$, tensile strength and elastic modulus results are discussed in this section.

Figure 4 presents the modified Proctor compaction results for raw sediments, stabilised sediments with 3\% lime (SS-3L) and stabilised sediments with $3 \%$ cement (SS-3C). It shows the dry density as function of water content. The maximum dry densities of raw sediments, SS-3C and SS-3L are 0.91, 0.93 and $0.95 \mathrm{~g} / \mathrm{cm}^{3}$, respectively. The increase in the maximum dry density by adding cement is related to the pore-filling effect of cementitious materials from a series of chemical reactions in binder, water and sediments. Compared to raw sediments, the addition of lime increases the optimum water content from 22 to $27 \%$. Indeed, lime hydrates rapidly, which results in increasing demand of the initial water mixture.

Figure 5 shows the immediate bearing capacity ratio $\left(I_{\mathrm{CBR}}\right)$ as function of water content of the three mixtures. At the optimum water content, the $I_{\mathrm{CBR}}$ values of raw sediments, SS-3C and SS-3L were $27,24.3$ and $59.4 \%$, respectively. The $I_{\mathrm{CBR}}$ value decreased from 27 to $24 \cdot 3 \%$ with addition of cement. The variation in $I_{\mathrm{CBR}}$ values depends on many factors such as mineralogical composition, pollutant content, water content, binder type and binder amount. Thus, the decrease in the $I_{\mathrm{CBR}}$ value can be related to the organic content of raw sediments $(12 \cdot 52 \%)$. Indeed, the presence of humic compounds in a soil complicates its treatment with cement. Humic acid has an inhibitory action on the hydraulic setting of the cement (Kujala and Makikyro, 1996; Liang and Levacher, 2012; Rey et al., 2000; Tremblay et al., 2002). It is also known that the presence of silt or clay affects the reaction between the soil and cement. Miura et al. (2001) demonstrated that the water content, the cement content and the curing period influence the properties of cement-treated clays. The presence of silt, a material that neither swells nor compresses, should improve the engineering properties of cement-treated soft clay by reducing the potential for recompression and settlement of the

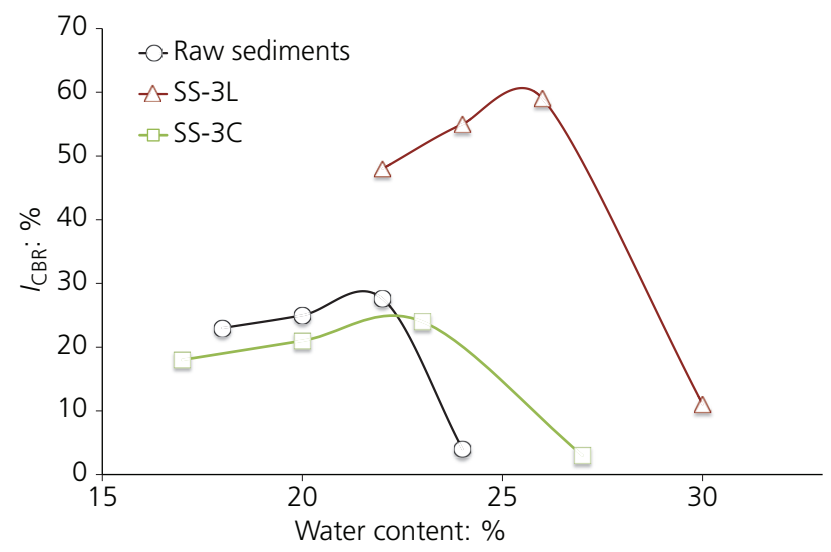

Figure 5. $I_{\text {CBR }}$ plotted against water content for raw sediments (black), SS-3L (red) and SS-3C (green) 
clay (Chairat and Panich, 2014). This is can be also a justification for the decrease in the $I_{\mathrm{CBR}}$ value for the SS-3C mixture.

The normal proceeding of cement stabilisation can be achieved by eliminating $\mathrm{OM}$ before treatment or by neutralising humic acid with a lime pretreatment. The reaction between lime and humic acid leads to the formation of calcium humates, which are not harmful with cement addition. Lime reduces the acidity of OM by neutralising pathogens that are responsible for presence of humic compound in sediments (Croise, 1964). It is recommended, for Zarzis sediment, to investigate combined lime-and-cement formulation in further work.

SS-3L presents the highest $I_{\mathrm{CBR}}$ value $\left(I_{\mathrm{CBR}}=59 \cdot 4 \%\right)$, thus corresponding to the best result. According to $I_{\mathrm{CBR}}$ results for raw sediments, SS-3C and SS-3L can be used as subgrade layers according to the NF P 98-115 standard.

Figure 6 shows the evolution of $U_{\mathrm{CS}}$ as a function of curing time. Depending on time, the assessment of the achieved mechanical performance differs from one formulation to another. It is clear that the mixture with $3 \%$ lime shows the highest values of $U_{\mathrm{CS}}$. Raw sediments and SS-3C show the same behaviour. The $U_{\mathrm{CS}}$ values for raw sediments and $\mathrm{SS}-3 \mathrm{C}$ are almost the same. It is clear that cement does not influence sediment treatment for the $U_{\mathrm{CS}}$ test.

A road layer is useful when its $U_{\mathrm{CS}}$ is greater than $1 \mathrm{MPa}$ (Sétra, 2000). From Figure 6, this value is not reached for raw sediments and SS-3C, and it is reached on the third day for SS-3L. This mixture presents a $U_{\mathrm{CS}}$ equal to $2.78 \mathrm{MPa}$ at $90 \mathrm{~d}$, while raw sediments and SS-3C show, respectively, $U_{\mathrm{CS}}$ values equal to 0.76 and $0.59 \mathrm{MPa}$ for the same curing time $(90 \mathrm{~d})$.

Table 4 gives the tensile strength $R_{\mathrm{t}}$ and the elastic modulus $E$ results of mixtures at 28 and $90 \mathrm{~d}$ of maturation. Figures 7 and 8 show the mechanical class of each mixture at 28 and $90 \mathrm{~d}$ of cure, respectively.

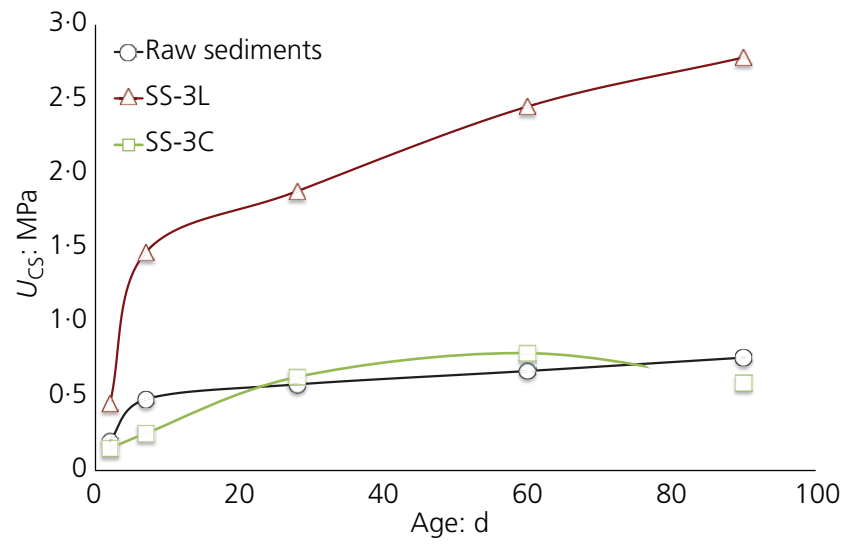

Figure 6. Unconfined compression $\left(U_{C S}\right)$ plotted against time for raw sediments (black), SS-3L (red) and SS-3C (green)
Table 4. Tensile strength, elastic modulus and classification at 28 and $90 \mathrm{~d}$ of maturation of mixtures: raw sediments, SS-3L and SS-3C

\begin{tabular}{|c|c|c|c|}
\hline Length of maturation: $d$ & Mixture & $R_{\mathrm{t}}: \mathrm{MPa}$ & $E: M P a$ \\
\hline \multirow[t]{3}{*}{28} & Raw sediments & $0 \cdot 12$ & 1480 \\
\hline & SS-3L & $0 \cdot 26$ & 2854 \\
\hline & SS-3C & $0 \cdot 15$ & 2206 \\
\hline \multirow[t]{3}{*}{90} & Raw sediments & $0 \cdot 14$ & 1860 \\
\hline & SS-3L & 0.33 & 3713 \\
\hline & SS-3C & $0 \cdot 19$ & 2295 \\
\hline
\end{tabular}

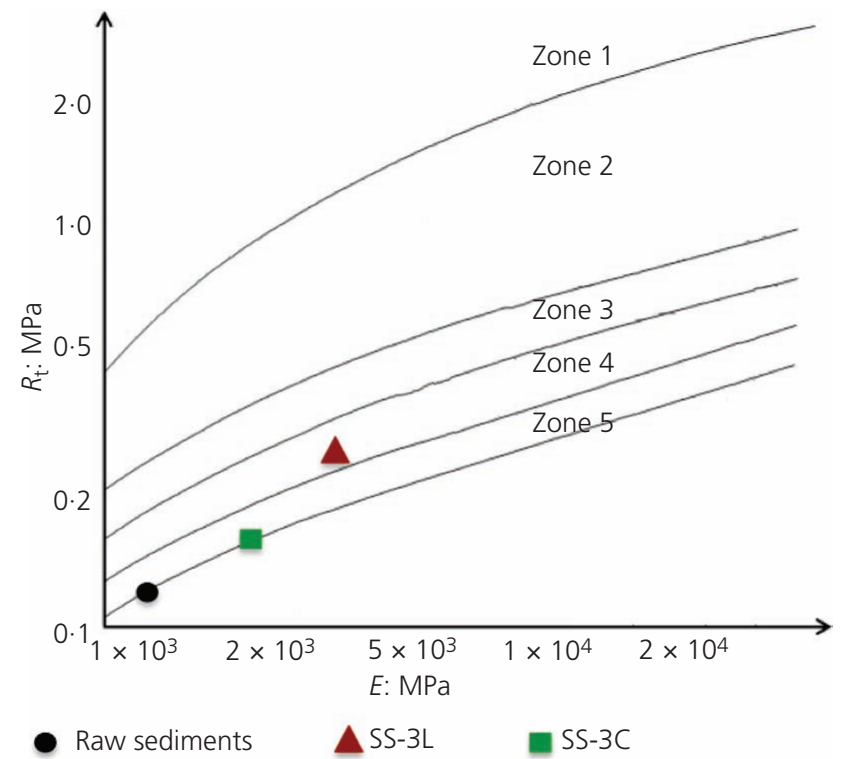

Figure 7. Classification of mixtures after $28 \mathrm{~d}$ of curing

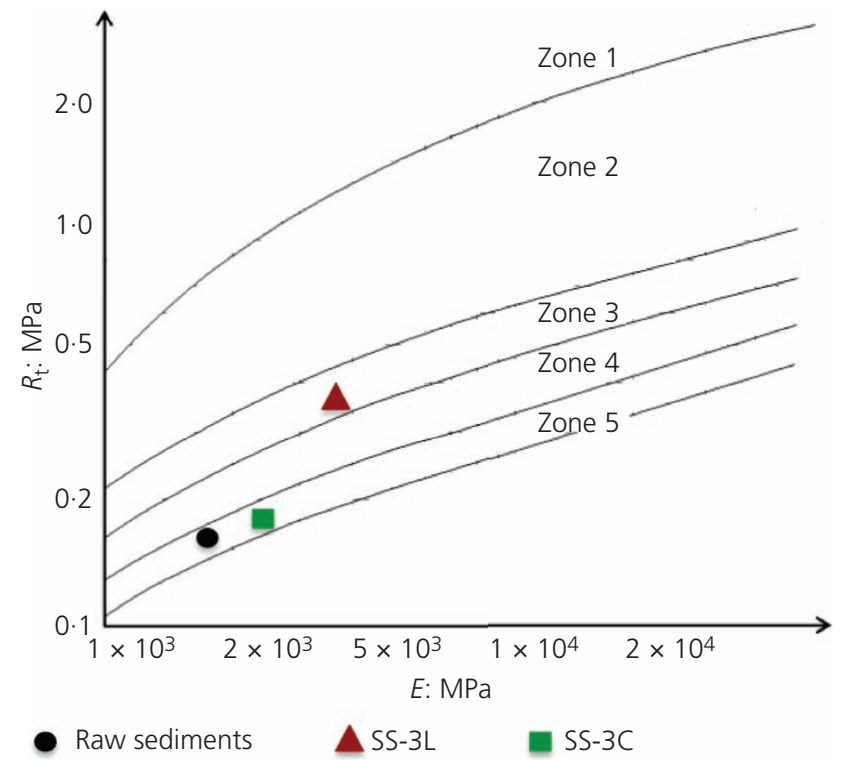

Figure 8. Classification of mixtures after $90 \mathrm{~d}$ of curing 
According to Scordia et al. (2008), the reuse of sediments represented a real technical and economic interest if the envisaged treatments were at least in zone 3. However, it is possible to use a treatment in zone 4 or 5 , but the thickness of the layer and the cost of its design become higher (Scordia et al., 2008). It can be observed that at $28 \mathrm{~d}$, none of the binders make it possible to achieve the fixed level of performance (zone 3). At $90 \mathrm{~d}$, SS-3L was located in zone 3. It is important to note that the classification zone was similar from 28 to $90 \mathrm{~d}$ of maturation for raw sediments and SS-3C. This similarity confirms the observations made during the compression tests where the maximum strengths of raw sediments and SS-3C were reached rapidly. In their research, Scordia et al. (2008) observed that at $28 \mathrm{~d}$, none of the binders make it possible to achieve zone 3 . On the other hand, at $90 \mathrm{~d}$, treatments with the hydraulic binder Roc Sol and lime are located in zone 3 .

\section{Conclusion}

This work aims to assess the feasibility of reusing dredged sediments in road construction. The tested sediments were dredged from a Tunisian harbour suffering from a silting problem. This issue generates a large amount of untreated sediments, so its reuse on road construction becomes an economic benefit. A subgrade layer consumes a large amount of raw materials, and the reserves of aggregates are theoretically almost limited. For these reasons, the choice of sediments to be reused in the subgrade layer was studied in this research.

Three mixtures were tested: raw sediments, stabilised sediments with 3\% lime (SS-3L) and stabilised sediments with 3\% cement (SS-3C).

The results show that the presence of humic compounds in sediments complicated their treatment with cement. Therefore, cement did not present an appropriate binder for stabilising and solidifying the tested sediments. SS-3L can be used as subgrade layer according to the $I_{\mathrm{CBR}}$ results. The $U_{\mathrm{CS}}$ demonstrated that a layer with the SS-3L mixture can be useful from the third day. Indeed, $U_{\mathrm{CS}}$ reached a value equal to $2.78 \mathrm{MPa}$ at $90 \mathrm{~d}$ of maturation, while raw sediments and the SS-3C mixture showed $U_{\mathrm{CS}}$ values equal to 0.76 and $0.59 \mathrm{MPa}$, respectively, at the same curing time $(90 \mathrm{~d})$.

Based on tensile strength and elastic modulus at $90 \mathrm{~d}$ of maturation, SS-3L was located in zone 3 according to the mechanical performance chart of the GTS (Sétra, 2000). Thus, the reuse SS-3L formulation is of real technical and economic interest.

This study highlighted the possibility of the reuse of stabilised sediments as a subgrade layer. The SS-3L samples showed satisfactory mechanical performance results. Indeed, the $I_{\mathrm{CBR}}$ value for SS-3L mixture was higher than the raw sediments and SS-3L mix results. From 2 to $90 \mathrm{~d}$ of maturation, $U_{\mathrm{CS}}$ ranged from 0.45 to $2 \cdot 78 \mathrm{MPa}$ for SS-3L, from 0.2 to $0.76 \mathrm{MPa}$ for raw sediments and from $0 \cdot 15$ to $0.59 \mathrm{MPa}$ for SS-3C.
According to the recommendations of the technical guide GTS (Sétra, 2000) and based on ITS and elastic modulus, SS-3L was located in zone 3, at $90 \mathrm{~d}$ of curing. For Zarzis sediments, cement was not an appropriate binder for improving sediment performance, contrary to Wang et al.'s (2012) research. Indeed, in Wang et al.'s (2012) study, the unconfined compressive strengths and tensile strengths increased with cement content and curing time and the mechanical performance of sediments solidified with cement was much superior to that of sediments solidified with lime.

In the literature, many research works recommended the investigation of combined cement and lime mixture. Zentar et al. (2008) studied the feasibility of reusing sediments in combination with cement and lime as alternative road materials. The optimisation procedure used to design the mix has shown its ability to improve the main characteristics of the raw fine sediments. In terms of engineering properties, such as $U_{\mathrm{CS}}, I_{\mathrm{CBR}}$ and elastic modulus, the added components have allowed the engineering characteristics of dredged fine sediments to increase substantially. Laboratory study has revealed the ability of the designed mix to be used as a sub-base material for a low intensity of road traffic. It is recommended to study the combined cement and lime mixture for Zarzis sediment in further works.

\section{Acknowledgements}

This study was funded by the partnership Hubert Cruien 'Utique' of the French Ministry of Foreign Affairs and the Tunisian Ministry of Higher Education and Scientific Research in Tunisia (Project Number 14 G 1116). The authors express their acknowledgements to the Tunisian Merchant Marine and Ports Office and the Tunis International Center for Environmental Technologies.

\section{REFERENCES}

Achour R (2013) Valorisation et caractérisation de la durabilité d'un matériau routier et d'un béton à base de sédiments de dragage. $\mathrm{PhD}$ thesis, École des mines de Douai, France, and Université de Sherbrooke, Sherbrooke, QC, Canada (in French).

Adams WJ, Kimerle RA and Barnett Jr (1992) Sediment quality and aquatic life assessment. Environmental Science and Technology 26(10): $1865-1875$.

Afnor (French Standardization Association) (1992a) NF P94-057: Soils: recognition and testing. Grading of soils. Sedimentation method. Afnor, Paris, France.

Afnor (1992b) NF P98-115: Roadbed: Execution of roadways. Constituents. Composition of mixtures and formulation. Execution and control. Afnor, Paris, France.

Afnor (1993a) NF P94-093: Soils: recognition and testing. Determination of compaction references of a material. Proctor Normal test. Modified Proctor test. Afnor, Paris, France.

Afnor (1993b) NF P98-230-2: Roadway testing: Preparation of materials treated with hydraulic binders or untreated - Part 2: manufacture of test specimens of sand or fine soils by static compression. Afnor, Paris, France.

Afnor (1995) NF P94-050: Soils: investigation and testing. Determination of moisture content. Oven drying method. Afnor, Paris, France.

Afnor (1996) NF P94 056: Soil: investigation and testing. Granulometric analysis. Dry sieving method after washing. Afnor, Paris, France.

Afnor (1998a) NF P94-068: Soils: recognition and testing. Measurement of the methylene blue adsorption capacity of a rocky soil. 
Determination of the methylene blue of a soil by means of the stain test. Afnor, Paris, France.

Afnor (1998b) XP P94-047: Soils: investigation and testing. Determination of the organic matter content. Ignition method. Afnor, Paris, France.

Afnor (2002) NF EN 12457-3: Characterisation of waste. Leaching. Compliance test for leaching of granular waste materials and sludges. Afnor, Paris, France.

Agostini F, Skoczylas F and Lafhaj Z (2007) About a possible valorisation in cementitious materials of polluted sediments after treatment. Cement and Concrete Composites 29(4): 270-278.

Barcelona Convention (2011) Convention for the Protection of the Marine Environment and the Coastal Region of the Mediterranean and Its Protocols. UN Environment Programme Mediterranean Action Plan, Athens, Greece, p. 143.

Boutouil M (1998) Traitement des vases de dragage par solidification/ stabilisation à base de ciment et additifs. $\mathrm{PhD}$ thesis, Université du Havre, Le Havre, France (in French).

Boutouil M and Saussaye L (2011) Influence de l'ajout d'un correcteur granulométrique sur les propriétés des sédiments traitées aux liants hydrauliques. Revue Paralia 4(8): 1-11 (in French).

Cai Y, Shi B, Charles W and Tang C (2006) Effect of polypropylene fiber and lime admixture on engineering properties of clayey soil. Engineering Geology 87(3-4): 230-240.

Chairat T and Panich V (2014) Influence of clay and silt proportions on cement-treated fine-grained soil. Journal of Materials in Civil Engineering 26(3): 420-428.

CJB Environnement Inc and EAM (Environmental Assessment \& Management) (2006) Etude d'identification des sites de rejet des matériaux de dragage dans les ports de commerce Tunisiens. Office de la Marine Marchande et des ports, Tunisia (in French).

Colin D (2003) Valorisation de sédiments technique routière. $\mathrm{PhD}$ thesis, Université de Caen, Caen, France (in French).

Croise R (1964) Traitement des sols aux liants hydrauliques. Ecole Nationale du Génie Rural, des Eaux et des Forêts, Nancy, France, pp. 427-438 (in French)

Czerewko MA and Cross SA (2015) The benefits of a granular interface over pyritic subgrade. Geotechnical Research 2(3): 97-122, https://doi. org/10.1680/jgere.15.00003.

DGE (Dutch-German Exchange) (2007) Status of Ecotoxicological Assessment of Sediment and Dredged Material in Germany and the Netherlands. Federal Institute of Hydrology, Koblenz, Germany.

Duan Z (2008) Caractérisation, stabilisation et solidification de sédiments fins marins. $\mathrm{PhD}$ thesis, Université de Caen, Caen, France (in French).

Dubois V, Abriak NE, Zentar R and Ballivy G (2009) The use of marine sediments as a pavement base material. Waste Management 29(2): $774-782$.

EC (European Community) (2008) Directive 2008/56/EC of the European Parliament and of the Council of 17 June 2008 establishing a framework for community action in the field of marine environmental policy (Marine Strategy Framework Directive). Official Journal of the European Communities L164/19.

Hamer K and Karius V (2002) Brick production with dredged harbour sediments: an industrial-scale experiment. Waste Management 22(5) 521-530.

Hu Z, Saman WRG, Ronald RN et al. (2006) Removal of PCDD/Fs and PCBs from sediment by oxygen free pyrolysis. Journal of Environmental Sciences 18(5): 989-994.

Ices (International Council for the Exploitation of the Sea) (2011) Report of the Working Group of the Effects of Extraction of Marine Sediments on the Marine Ecosystem. Ices, Delft, the Netherlands.

IMO (International Maritime Organization) (1972) Convention on the Prevention of Marine Pollution by Dumping of Wastes and Other Matter. IMO, London, UK.

IMO (2013) Specific Guidelines for the Assessment of Dredged Material. IMO, London, UK.
Kamali S, Bernard F, Abriak NE and Degrugilliers P (2008) Marine dredged sediments as new materials resource for road construction. Waste Management 28(5): 919-928.

Kujala K and Makikyro M (1996) Effect of humus on the binding reaction in stabilized soils. In Grouting and Deep Mixing (Shibazaki M, Terashi M and Yonekura R (eds)). Balkema, Rotterdam, the Netherlands, pp. 415-420.

Lafhaj Z, Samara M, Agostini F et al. (2008) Polluted river sediments from the north region of France: treatment with Novosol ${ }^{\circledR}$ process and valorization in clay bricks. Construction and Building Materials 22(5): $755-762$.

Le Guyader C and Colin F (2012) Enquête 'Dragage 2009' Synthèse des données. Centre d'Etudes Techniques Maritimes et fluviales, Ministère de l'écologie, du développement durable, des transports et du logement, Paris, France, pp. 1-39 (in French).

Leroueil S and Le Bihan JP (1996) Liquid limits and falling cones. Canadian Geotechnical Journal 33(5): 793-798.

Liang Y (2012) Co-valorisation de sédiments et de sols fins par apport de liants et de fibres. PhD thesis, Université de Caen, Caen, France (in French).

Liang Y and Levacher D (2012) Gestion durable de sédiments méditerranéens: influence des propriétés physiques et chimiques sur le comportement mécanique des procédés de $\mathrm{S} / \mathrm{S}$ à base de ciment et de chaux. In Journées Nationales Génie Côtier - Génie Civil, No. 12 (2012) Cherbourg (Levacher D, Sanchez M and Guillou S (eds)). Editions Paralia, Centre Français du Littoral, Nantes, France, pp. 1049-1058 (in French).

Limeira J, Etxeberria M, Agulló L and Molina D (2011) Mechanical and durability properties of concrete made with dredged marine sand. Construction and Building Materials 25(11): 4165-4174.

Maher A, Douglas WS and Jafari F (2006) Field placement and evaluation of stabilized dredged material (SDM) from the New York/New Jersey Harbor. Marine Georesources \& Geotechnology 24(4): 251-263.

Michel F (2006) Les granulats. Union des Producteurs de Granulats, France.

Miura N, Horpibulsuk S and Nagaraj TS (2001) Engineering behavior of cement stabilized clay at high water content. Soils and Foundation 41(5): 33-45.

Mohd Yunus NZ, Wanatowski D, Marto A and Jusoh SN (2017) Strength improvement of lime-treated clay with sodium chloride. Geotechnical Research 4(4): 192-202, https://doi.org/10.1680/jgere.17.00001.

Ospar (Oslo/Paris) Convention (1992) Convention for the Protection of the Marine Environment of the North-east Atlantic, Paris, France.

Rey F, Levacher D and Quenech J (2000) La valorisation par solidification/ stabilisation à base de chaux et additifs de vases de dragage: résultats et perspectives. In Journées Nationales Génie Côtier - Génie Civil, No. 6 (2000) Caen (Levacher D (ed.)). Editions Paralia, Centre Français du Littoral, Nantes, France, pp. 377-386 (in French).

Rosenberg R (1977) Effects of dredging operations on estuarine benthic macrofauna. Marine Pollution Bulletin 8(5): 102-104.

Said I, Missaoui A and Lafhaj Z (2015) Reuse of Tunisian marine sediments in paving blocks: factory scale experiment. Journal of Cleaner Production 102(3): 66-77.

Saussaye L (2013) Traitement des sols aux liants hydrauliques: aspects géotechniques et physico-chimiques des perturbations de la solidification. $\mathrm{PhD}$ thesis, Université de Caen. Caen, France (in French).

Scordia PY, Lafhaj Z, Skoczylas F and Mongouin T (2008) Characterization and valorization of polluted and treated river sediments in road. European Journal of Environmental and Civil Engineering 7(4): 451-469.

Sétra (Service d'études techniques des routes et autoroutes) (2000) Treatment of Soils with Lime and/or Hydraulic Binders: Application to the Construction of Pavement Base Layers. Sétra, Bagneux, France.

Silitonga E (2010) Valorisation des sédiments marins contaminés par solidification/stabilisation à base de liants hydrauliques et de fumée de silice. PhD thesis, Université de Caen, Caen, France (in French). 
Geotechnical Research

Volume 5 Issue GR1
Experimental testing for Zarzis port sediments (Tunisia) in road materials Zelleg, Said, Hamdi and Lafhaj
Tran NT (2009) Valorisation de sédiments marins et fluviaux en technique routière. $\mathrm{PhD}$ thesis, Ecole Nationale Supérieure des Mines de Douai, Douai, France (in French).

Tremblay H, Duchesne J, Locat J and Leroueil S (2002) Influence of the nature of organic compounds on fine soil stabilization with cement. Canadian Geotechnical Journal 39(3): 535-546.

Wang HY (2009) Durability of self-consolidating lightweight aggregate concrete using dredged silt. Construction and Building Materials 23(6): 2332-2337.
Wang DX, Abriak NE, Zentar R and Xu W (2012) Solidification stabilization of dredged marine sediments for road construction. Environmental Technology 33(1): 95-101.

Weng CH, Lin DF and Chiang PC (2003) Utilization of sludge as brick materials. Advances in Environmental Research 7(3): 679-685.

Zentar R, Dubois V and Abriak NE (2008) Mechanical behaviour and environmental impacts of a test road built with marine dredged sediment. Resources, Conservation and Recycling 52(6): 947-954.

\section{How can you contribute?}

To discuss this paper, please submit up to 500 words to the editor at journals@ice.org.uk. Your contribution will be forwarded to the author(s) for a reply and, if considered appropriate by the editorial board, it will be published as a discussion in a future issue of the journal. 